\title{
АПЕЛЯЦЙНЕ ТА КАСАЦІЙНЕ ОСКАРЖЕННЯ АДМІНІСТРАТИВНИХ СПРАВ НЕЗНАЧНОЇ СКЛАДНОСТІ (МАЛОЗНАЧНІСТЬ СПРАВ)
}

Постановка проблеми. Вже практично чотири роки як процесуальними кодексами України було запроваджено категорію малозначних справ, а адміністративне судочинство здійснюється в порядку загального або спрощеного позовного провадження. За задумом законодавця, інститут малозначності справи, як один із процесуальних фільтрів, покликаний спростити доступ громадян до судочинства, розвантажити суди, які розглядатимуть адміністративні справи в фактично письмовому провадженні без участі сторін, інших учасників процесу, без дослідження доказів і судових дебатів.

Зміни до Конституції України щодо правосуддя закріпили забезпечення реалізації права на апеляційний перегляд справи та лише у визначених законом випадках - права на касаційне оскарження судового рішення (ст. 129 Конституції України [1]. У зв'язку із цим до процесуальних кодексів внесено ряд змін та доповнень, які врегульовують особливості апеляційного оскарження окремих категорій адміністративних справ, у тому числі малозначних, та спрямовані на обмеження кола справ, що можуть підлягати касації аж до повної заборони останньої.

Актуальність статті зумовлена необхідністю проаналізувати право та порядок апеляційного та касаційного оскарження малозначних справ у адміністративному судочинстві України. Аналіз спеціальної наукової літератури свідчить про певне висвітлення даної проблеми, але зміни законодавства про адміністративне судочинство та судова практика потребують нового осмислення та аналізу.

Метою статті є з'ясування особливостей апеляційного та касаційного оскарження малозначних справ в адміністративному судочинстві.

Виклад основного матеріалу дослідження. За загальними правилами теорії права, адміністративні справи є однією із категорій судових справ (юрисдикційних справ). У ст. 263 гл. 10 Кодексу адміністративного судочинства України (далі - КАС України) йдеться про категорії справ незначної складності (що розглядаються у письмовому провадженні), хоча сама глава має назву «Розгляд справ за правилами спрощеного позовного провадження» (тобто розгляд не категорій справ, але урахування категорії і складності справи під час вирішення питання про розгляд справи за правилами спрощеного або загального позовного провадження (ч. 3 ст. 257 КАС України).

КАС України дає формулювання трьом видам адміністративних справ, не вказуючи при цьому, що це саме певні види: незначної складності (малозначна справа) - адміністративна справа, у якій характер спірних правовідносин, предмет доказування та склад учасників тощо не вимагають проведення підготовчого провадження та (або) судового засідання для повного та всебічного встановлення 
iï обставин (п. 20 ст. 4); типові адміністративні справи - адміністративні справи, відповідачем у яких є один і той самий суб’єкт владних повноважень (його відокремлені структурні підрозділи), спір у яких виник з аналогічних підстав, у відносинах, що регулюються одними нормами права, та у яких позивачами заявлено аналогічні вимоги (п. 21 ст. 4); зразкова адміністративна справа - типова адміністративна справа, прийнята до провадження Верховним Судом як судом першої інстанції для постановлення зразкового рішення (п. 22 ст. 4).

Як бачимо, закон визначає різноманітні критерії віднесення адміністративної справи до тієї чи іншої категорії та до того чи іншого виду. Одна й та сама справа за видом може бути як малозначною, так і типовою, а також зразковою. КАС України визначає належність адміністративної справи до того чи іншого виду у такому вигляді: до справ незначної складності - 11 видів; до складних справ - 3 категорії; до термінових справ - 15 категорій [2, с. 27-33].

При цьому перелік справ незначної складності (ч. 6 ст. 12) сформований на підставі не лише тих чи інших категорій, а й різновидів (типові справи), і має невичерпний характер. Відсутність у кодексі чіткого переліку малозначних справ привертає неабияку увагу у світлі перспектив таких справ бути оскарженими в апеляційному та касаційному порядку.

Із визначення, поданого у п. 20 ч. 1 ст. 4 КАС України (адміністративна справа незначної складності (малозначна справа), неможливо встановити виразні риси малозначної, іншими словами нескладної справи. Слід сказати, що дане визначення є єдиною нормою у КАС України, де використовується термін «малозначна справа» . Далі КАС України містить поняття «справа незначної складності», «спрощене позовне провадження», «інші справи, для яких пріоритетним є швидке вирішення справи» тощо, але терміну «малозначна» уникає [3]. Слід погодитися з думками науковців, які зазначають, що «використаний термін «малозначні» доволі специфічний, оскільки значення справи для заявника не залежить від його ціни або складності розгляду і навряд чи варто ділити справи на значні та малозначні» [4, с. 18].

Для справ незначної складності (малозначних справ) передбачено вирішення в спрощеному порядку. Спрощене позовне провадження призначене для розгляду справ незначної складності та інших справ, для яких пріоритетним є швидке вирішення справи (ст. 12 КАС України). Із цього видно, що коло справ, яке й до того було не чітко визначене за критеріями «не вимагають проведення підготовчого провадження та (або) судового засідання для повного та всебічного встановлення iï обставин», значно розширюється за рахунок «інші справи, для яких пріоритетним є швидке вирішення справи». Наявність положення у змісті статті «інші справи, у яких суд дійде висновку про їх незначну складність, за винятком справ, які не можуть бути розглянуті за правилами спрощеного позовного провадження» - дає волю у віднесенні тієї чи іншої справи до категорії малозначних практично до нескінченності. Потенційно - це будь-яка справа, яка не віднесена КАС України до справ незначної складності та яка не обов'язково розглядається за правилами загального провадження.

«Захищеними» від можливості бути віднесеними до малозначних є справи, перелік яких передбачений ч. 4 ст. 12 КАС України. Це справи: 1) щодо оскарження 
нормативно-правових актів, за винятком випадків, визначених цим Кодексом; 2) щодо оскарження рішень, дій та бездіяльності суб’єкта владних повноважень, якщо позивачем також заявлено вимоги про відшкодування шкоди, заподіяної такими рішеннями, діями чи бездіяльністю, у сумі, що перевищує п’ятсот розмірів прожиткового мінімуму для працездатних осіб; 3) про примусове відчуження земельної ділянки, інших об'єктів нерухомого майна, що на ній розміщені, з мотивів суспільної необхідності; 4) щодо оскарження рішення суб’єкта владних повноважень, на підставі якого ним може бути заявлено вимогу про стягнення грошових коштів у сумі, що перевищує п'ятсот розмірів прожиткового мінімуму для працездатних осіб; 5) щодо оскарження рішень Національної комісії з реабілітації у правовідносинах, що виникли на підставі Закону України «Про реабілітацію жертв репресій комуністичного тоталітарного режиму 1917-1991 років»; 6) щодо оскарження індивідуальних актів Національного банку України, Фонду гарантування вкладів фізичних осіб, Міністерства фінансів України, Національної комісії з цінних паперів та фондового ринку, рішень Кабінету Міністрів України, визначених ч. 1 ст. $266^{-1}$ цього Кодексу. Упродовж останніх двох років вказаний перелік було розширено, що можна розглядати як позитивний крок законодавця на шляху деталізації правового регулювання адміністративних справ незначної складності (малозначних справ).

Проаналізувавши норми КАС України, можна виділити такі особливості справ незначної складності (малозначних справ), серед яких варто відзначити основні:

1) малозначні справи розглядаються в порядку спрощеного позовного провадження;

2) у малозначних справах представником може бути особа, яка не є адвокатом, але за умови, що вона досягла вісімнадцяти років та має цивільну процесуальну дієздатність;

3) за загальним правилом, рішення у малозначних справах не підлягають оскарженню в касаційному порядку.

На практиці суддя може перейти зі спрощеного провадження в загальне, а от роздумати і визнати не малозначною справу, яку він вже визнав малозначною, не може. Залишається одне - продовжувати розгляд складної справи як малозначної - а отже, і у спрощеному провадженні, бо не може суд розглядати справу, визнану ним малозначною не в спрощеному провадженні. I в даному випадку навіть більшою проблемою буде не те, як розглядатиме справу суд, а те, що така справа може бути оскаржена до апеляційної інстанції, але не підлягає наступному оскарженню в касаційній інстанції.

Згідно з п. 6 ч. 3 ст. 2 КАС України забезпечення права на апеляційний перегляд справи є однією із основних засад (принципів) адміністративного судочинства. КАС України (редакції від 15.12.2017) у ст. 297 закріплює новий порядок подання апеляційної скарги безпосередньо до суду апеляційної інстанції у письмовій формі. Зазначене нововведення призначене для якнайшвидшого прийняття та прискорення прийняття до розгляду апеляційного скарги судом апеляційної інстанції.

Загалом апеляційний перегляд адміністративних справ єдиний для усіх категорій та видів адміністративних справ. 
Так, апеляційний розгляд здійснюється колегією суддів у складі трьох суддів за правилами розгляду справи судом першої інстанції за правилами спрощеного позовного провадження з урахуванням особливостей, встановлених КАС України (ст. 310). Подання апеляційної скарги на рішення суду першої інстанції, які ухвалені в порядку спрощеного позовного провадження без повідомлення сторін (у порядку письмового провадження), суд апеляційної інстанції може розглянути без повідомлення учасників справи (в порядку письмового провадження) за наявними у справі матеріалами, якщо справу може бути вирішено на підставі наявних у ній доказів (ст. 311).

За наслідками розгляду апеляційної скарги на судове рішення суду першої інстанції суд апеляційної інстанції має право скасувати судове рішення повністю або частково і ухвалити нове судове рішення у відповідній частині або змінити судове рішення в результаті неправильного застосування норм матеріального права або порушення норм процесуального права. Порушення норм процесуального права є обов'язковою підставою для скасування судового рішення та ухвалення нового рішення суду, зокрема якщо суд розглянув за правилами спрощеного позовного провадження справу, яка підлягала розгляду за правилами загального позовного провадження (п. 7 ч. 3 ст. 317 ).

Із касаційним оскарженням судових рішень в адміністративних справах не все так однозначно. У ч. 5 ст. 328 КАС України визначено: «Не підлягають касаційному оскарженню: судові рішення у справах незначної складності». Особи, які беруть участь у справі, у разі, якщо не погоджуються із ухваленими судовими рішеннями після їх перегляду в апеляційному порядку, можуть скористатися правом їх оскарження у касаційному порядку лише у визначених законом випадках.

Такий касаційний фільтр, що з'явився у законодавстві у 2017 році, розвантажив Верховний Суд і пришвидшив остаточне вирішення спору, але водночас позбавив сторони можливості оскаржити рішення апеляційного суду.

Верховний Суд у складі колегії суддів Касаційного адміністративного суд у своїй ухвалі від 30 січня 2020 року у справі № 140/1935/19 застосував практику ЄСПР стосовно касаційних фільтрів [5].

Так, Велика Палата Свропейського суду з прав людини у своєму рішенні від 05 квітня 2018 року (справа «Зубац проти Хорватіï (Zubac v.Croatia), № 40160/12) вказала, що право на доступ до суду не є абсолютним і може підлягати обмеженням, які дозволяються опосередковано, оскільки право на доступ до суду за своєю природою потребує регулювання державою, і таке регулювання може змінюватися у часі та місці відповідно до потреб та ресурсів суспільства та окремих осіб (див. «Станєв проти Болгаріï (Stanev v. Bulgaria), № 36760/06, п. 230, ЄСПЛ 2012 ) (п. 78). Спосіб застосування п. 1 ст. 6 Конвенції до апеляційних та касаційних судів залежить від особливостей судового провадження, про яке йдеться, і необхідно враховувати всю сукупність процесуальних дій, проведених в рамках національного правопорядку, а також роль судів касаційної інстанції в них; умови прийнятності касаційної скарги щодо питань права можуть бути суворіші, ніж для звичайної скарги (п. 82). 
Відповідно до п. 83 вказаного вище рішення застосування передбаченого законодавством порогу ratione valoris для подання скарг до верховного суду є правомірною та обгрунтованою процесуальною вимогою, враховуючи саму суть повноважень верховного суду щодо розгляду лише справ відповідного рівня значущості.

Крім того, Свропейський суд з прав людини звернув увагу на те, що саме національний верховний суд, якщо цього вимагає національне законодавство, повинен оцінювати те, чи досягнуто передбачений законодавством поріг ratione valoris для подання скарги саме до цього суду. Відповідно, в ситуації, коли відповідне національне законодавство дозволяло йому відфільтровувати справи, що надходять до нього, верховний суд не може бути зв язаний або обмежений помилками в оцінюванні зазначеного порогу, яких припустилися суди нижчої інстанції при визначенні того, чи надавати доступ до нього (рішення у справі «Добріч проти Сербії», п. 54) (п. 86).

09 жовтня 2018 року Свропейський суд з прав людини постановив ухвалу щодо неприйнятності заяви № 26293/18 у справі «Азюковська проти України» (Azyukovska v. Ukraine), у якій зазначив, що застосування критерію малозначності справи у справі було передбачуваним, справа була розглянута судами двох інстанцій, які мали повну юрисдикцію, заявниця не продемонструвала наявності інших виключних обставин, які за положеннями кодексу могли вимагати касаційного розгляду справи (п. 20-22).

Отже, за прецедентною практикою Європейського суду з прав людини обмеження доступу до Верховного Суду охоплюється загальновизнаною легітимною метою встановленого законодавством порогу ratione valoris для скарг, що подаються на розгляд Верховного Суду, яка полягає в тому, щоб забезпечувати розгляд у Верховному Суді з огляду на саму суть його функцій, лише справ необхідного рівня значущості.

Згідно з п. 2 ч. 5 ст. 328 КАС України не підлягають касаційному оскарженню: 1) рішення, ухвали суду першої інстанції та постанови, ухвали суду апеляційної інстанції у справах, рішення у яких підлягають перегляду в апеляційному порядку Верховним Судом; 2) судові рішення у справах незначної складності та інших справах, розглянутих за правилами спрощеного позовного провадження (крім справ, які відповідно до КАС України розглядаються за правилами загального позовного провадження), крім випадків, якщо: а) касаційна скарга стосується питання права, яке має фундаментальне значення для формування єдиної правозастосовчої практики; б) особа, яка подає касаційну скаргу, відповідно до цього Кодексу позбавлена можливості спростувати обставини, встановлені оскарженим судовим рішенням, під час розгляду іншої справи; в) справа становить значний суспільний інтерес або має виняткове значення для учасника справи, який подає касаційну скаргу; г) суд першої інстанції відніс справу до категорії справ незначної складності помилково.

Системний аналіз наведених вище положень дає підстави для висновку, що суд має право віднести справу до категорії малозначних за результатами оцінки характеру спірних правовідносин, предмету доказування, складу учасників та інших обставин, крім випадків, передбачених частиною четвертою ст. 12 КАС України. 
Суд у кожному конкретному випадку враховує характер правовідносин, із приводу прав і обов язків сторін, в яких виник спір, що є предметом судового розгляду в конкретній адміністративній справі, предмет доказування, обставини, встановлені судами першої та апеляційної інстанцій, а також доводи касаційної скарги, вирішує, чи підпадає адміністративна справа під критерії визначення справи незначної складності.

Верховним Судом повинні бути досліджені та взяті до уваги: предмет позову, складність справи та застосування законодавства на час спірних правовідносин, а також значення справи для сторін та суспільства, які дає можливість дійти висновку про малозначність справи. Суд повинен дослідити усі обставини та факти, які б виключали можливість застосування положень п. 2 ч. 5 ст. 328 КАС України. Учасник справи повинен самостійно викласти у касаційній скарзі наявність таких застережень.

Для застосування касаційного фільтра необов'язковим є визнання судом першої інстанції справи малозначною. Достатньо, щоб вона підпадала під ознаки малозначної, установлені законом. На це неодноразово звертав увагу Верховний Суд.

Зокрема, у справі № 927/5/18 він наголосив, що розгляд у порядку спрощеного позовного провадження, яке притаманне саме малозначним справам, свідчить про визнання справи такою, навіть за відсутності прямої вказівки на це в описовій чи резолютивній частині судового рішення. У справі № 684/865/18 Верховний Суд констатував, що «малозначною справа є в силу своїх властивостей, незалежно від того, визнав її такою суд першої чи апеляційної інстанції» [6].

Незважаючи на це, подача касаційних скарг на судові рішення у справах незначної складності не припиняється й досі.

Противників касаційних фільтрів майже немає. Загалом ставлення суддів до касаційних фільтрів позитивне, адвокатів - нейтральне [6].

Також слід зазначити, що у червні 2019 року на сайті електронних петицій була зареєстрована петиція № 22/061032-еп з вимогою забезпечити громадянам України право касаційного оскарження рішень суддів по всім справам у тому числі і по малозначним [7]. Утім, петиція не набула розголосу та не отримала підтримки.

Висновки. Запровадження касаційних фільтрів відповідає принципу правової визначеності, на необхідність дотримання якого неодноразово вказував Європейський суд з прав людини. Жодна зі сторін не має права вимагати перегляду остаточного судового рішення лише через бажання нового вирішення справи. Касаційний перегляд не повинен замінювати апеляційний. Натомість існування двох різних поглядів на один предмет не є підставою для нового слухання справи.

Таким чином, інститут перегляду малозначних справ, що включає касаційні фільтри, є позитивною новелою, спрямованою на пришвидшення остаточного вирішення справи, розвантаження суддів та адвокатів. Перспективним $є$ подальше вдосконалення цього інституту шляхом внесення змін до процесуального законодавства та формування правозастосовної практики Верховного Суду. Все-таки об’єктивних підстав для звуження касаційних фільтрів наразі немає. А у визначених справах згідно з ч. 6 ст. 12 КАС України рішення апеляційних адміністра- 
тивних судів не оскаржуються до касаційного суду, тому саме апеляційні адміністративні суди формують остаточну судову практику з врахуванням кращих європейських та вітчизняних традицій.

Загалом пришвидшений розгляд справ незначної складності (малозначних справ) є доцільним нововведенням, однак за умови його чіткого регулювання процесуальними кодексами.

Підсумовуючи, висловлюємо сподівання, що професійна інтуїція не підведе правозастосовувачів, а запроваджені зміни законодавства слугуватимуть його цілям та завданням.

\section{Jimepamypa}

1. Конституція України. URL : https://zakon.rada.gov.ua/laws/show/254 /96.

2. Качур I.А. Законодавча класифікація адміністративних справ в адміністративному судочинстві України. Наукові записки Інституту законодавства Верховної Ради Украӥни. 2018. № 2. С. 27-33. URL : http://nbuv.gov.ua/UJRN/Nzizvru_2018_2_6.

3. Кучер Ю. Малозначність справ адміністративної юрисдикції. Вісник Національної академії Державної прикордонної служби України Серія: юридичні науки 2018 № 7. URL : http://www.irbis-nbuv.gov.ua/cgi-bin/irbis_nbuv/cgiirbis_64.exe?C21COM=2\&I21DBN=UJRN\& P21DBN=UJRN\&IMAGE_FILE_DOWNLOAD=1\&Image_file_name=PDF/vnadpcurn_2018_2_13.pdf.

4. Ізарова I.O. Реформи цивільного процесуального законодавства в незалежній Україні: 1991-2017. Україна на шляху до Європи: реформа цивільного процесуального законодавства. Київ, 2017. С. 18.

5. Ухвала Верховного Суду від 30 січня 2020 року, справа № 140/1935/19. URL : http://iplex.com.ua/doc.php?regnum=87297233\&red.

6. Шишка Юлія Найбільше шансів на касаційний перегляд мають малозначні адміністративні справи, найменше - господарські Закон і бізнес 10.08-21.08.2019. URL : https://zib.com.ua/ua/ 138824-naybilshe_shansiv_na_kasaciyniy_pereglyad_mayut_maloznachni_html.

7. Електронні петиції / Офіційне інтернет-представництво Президента України. URL : https://petition.president.gov.ua/petition/61032.

\section{Анотація}

Серватюк Л. В., Кучер Ю. А. Апеляційне та касаційне оскарження адміністративних справ незначної складності (малозначність справ). - Стаття.

У статті здійснено аналіз змісту поняття справа незначної складності (малозначна справа) в адміністративному судочинстві України. Зроблена спроба визначити сутність поняття «малозначна справа" в розумінні Кодексу адміністративного судочинства України, а також з'ясувати місце малозначних справ серед усіх категорій справ, що розглядаються в порядку адміністративного судочинства.

Звертається увага на те, що п. 20 ч. 1 ст. 4 КАС є єдиною нормою, де використовується термін «малозначна справа». Далі КАС використовує поняття "справа незначної складності», "спрощене позовне провадження», «інші справи, для яких пріоритетним $€$ швидке вирішення справи» тощо.

Відповідно до чинного законодавства касаційний перегляд малозначних справ не передбачено. Однак Верховний суд може прийняти малозначну справу до розгляду за наявності таких умов: якщо касаційна скарга стосується питання, яке має фундаментальне значення для формування єдиної правозастосовної практики; якщо особа, яка подає касаційну скаргу, позбавлена можливості спростувати обставини, встановлені оскарженим судовим рішенням, під час розгляду іншої справи; якщо справа становить значний суспільний інтерес або має виняткове значення для учасника справи, який подає касаційну скаргу або суд першої інстанції відніс справу до категорії малозначних помилково.

Розглянуто особливості реалізації права на апеляційне та касаційне оскарження малозначних справ в адміністративному судочинстві України у світлі нововведень законодавства України, вітчизняної судової практики та практики Європейського суду з прав людини.

Системний аналіз положень статті дає підстави для таких висновків: суд має право віднести справу до категорії малозначних за результатами оцінки характеру спірних правовідносин, предмету доказування, складу учасників та інших обставин, крім випадків, передбачених частиною четвертою 
ст. 12 КАС України; для застосування касаційного фільтра не обов’язковим є визнання судом першої інстанції справи малозначною. Достатньо, щоб вона підпадала під ознаки малозначної, установлені законом; запровадження касаційних фільтрів відповідає принципу правової визначеності, на необхідність дотримання якого у своїх рішеннях вказує Європейський суд із прав людини.

Ключові слова: адміністративне судочинство, адміністративна справа, справи незначної складності, малозначність справ в адміністративному судочинстві, право на апеляційне й касаційне оскарження.

\section{Summary}

Servatyuk L. V., Kucher Yu. A. Appeal and cassation appeal of administrative cases of insignificant complexity (insignificance of cases). -Article.

The article analyzes the content of the concept of a case of insignificant complexity (insignificant case) in the administrative proceedings of Ukraine. An attempt is made to define the essence of the concept of minor case in the sense of the Code of Administrative Procedure of Ukraine, as well as to clarify the place of minor cases among all categories of cases considered in administrative proceedings.

Attention is drawn to the fact that paragraph 20, part 1 of Article 4 of the Code of Administrative Procedure of Ukraine is the only rule where the term minor case is used. Further, Code of Administrative Procedure of Ukraine uses the terms case of insignificant complexity, simplified litigation, other cases for which the priority is to resolve the case quickly.

According to the current legislation, the cassation review of minor cases is not provided, but the Supreme Court may accept a minor case for consideration in the following conditions: if the cassation appeal concerns an issue that is fundamental for the formation of a single law enforcement practice; if the person filing the cassation appeal is deprived of the opportunity to refute the circumstances established by the appealed court decision when considering another case; if the case is of significant public interest or is of exceptional importance for the party to the case who files a cassation appeal or the court of first instance classified the case as insignificant.

Peculiarities of realization of the right to appellate and cassation appeal of insignificant cases in administrative proceedings of Ukraine in the light of innovations of the legislation of Ukraine, domestic judicial practice and practice of the European Court of Human Rights are considered.

A systematic analysis of the provisions of the article gives grounds for the following conclusions: the court has the right to classify the case as insignificant according to the results of assessing the nature of the disputed legal relationship, the subject of proof, the composition of participants and other circumstances, except as provided in part four of Art. 12 Code of Administrative Procedure of Ukraine; it is not necessary for the court of first instance to recognize the case as insignificant in order to apply the cassation filter. It is sufficient that it fall under the signs of insignificance established by law; the introduction of cassation filters complies with the principle of legal certainty, the need for which the European Court of Human Rights points out in its decisions.

Key words: administrative proceedings, administrative case, cases of insignificant complexity, insignificance of cases in administrative proceedings, the right to appeal and cassation appeal. 